\title{
Strengthening Quality Of School Based On Accreditation At Boarding School
}

\author{
Sitti Roskina Mas ${ }^{\mathrm{a}}$, Yulan Radji ${ }^{\mathrm{a}}$ \\ a Universitas Negeri Gorontalo, Indonesia
}

Corresponding e-mail: sittiroskina@ung.ac.id

\begin{abstract}
The research objectives were to find out to (1) leadership and teacher commitment in strengthening quality based on accreditation, (2) students' commitment to maintain quality of MAN IC Gorontalo. The research used a qualitative descriptive research with case study design. Data were taken from head master, vice head master, teachers, and students. Techniques of data collections were observation, interview, and documents. Data were analyzed qualitatively by using collection, reduction, display, and conclusion. Data validations were used data credibility with triangulation. The research findings indicated that (1) leadership and teachers' commitment in maintaining quality of students with based accreditation were done through (a) fulfill SNP requirement according to national standard, (b) modified standard curriculum according to Cambridge International Standard in MAFIKIBI plus Economy and Geography, (c) matriculation program in MAFIKIBI plus Economy and Geography, (d) Local contents and learnt to memorize Al Qur'an, and KIR, (e) students' achievement were assessed based on cognitive, affective, and psychomotor and supported by Information Technology with SIMANIC application and (f) quality control of assessment, students themselves; and (2) students' commitment by (a) maintaining quality through honesty value, (b) followed the rules of school, (c) care each other's, (d) take care commitment and human relationship, (e) onus to do duties, (f) protect of school from good values, (g) commit to achieve local, regional, national, and international achievement, (h) to do the KING, excellent, SCIC, friendship competition.
\end{abstract}

Keywords: strengthening quality, accreditation based, boarding school

\section{INTRODUCTION}

The quality assurance in educational institutuion has importance aspect because it is become instruments for educational process has been done well, and so that education can be evaluated, improved continuously fro giving very excellent services for students, parents, and other stake holders [1]; [2]; Arcaro, 2006; [3]; [4]; [5]).The school quality assurance can give two important information, (1) feedback to schools, (2) quality assurance to parents that schools have given excellent services to students. The importance of quality assurance has been stated at Decision of Government No. 19 year 2005 article 91 point 1 that all educational institution include formal and non formal education have to implemented quality assurance in education.

One way that have been done the government in implementing quality assurance in national education and developing quality of education with good sustainable planning are to do accreditation to assess the visibility of educational program (The Government Low No. 20 year 2003). In implementing the government low in educational accreditation, Ministery of National Education have stated at the Decision No. 087/U/2002 about school accrediatation. The all education levels, public schools and private schools vave to accreditated. The visibility of educational institution have to fulfill facilities, human resources, management, school administration, and other components that supported national educationbal standards.

Based on this decision, the government havedicided School National Accrediation Institution (BAN-S/M) with Ministery of National Education Decision No. 29 year 2005. BAN -S/M is an independent evaluation that has to state and assess visibility of in each educational level, basic education, and high school education. BAN-S/M has to formulate operational decision of public schools and provate schools that become main point for quality assurance national education. The using of comprehensive accreditation instruments are developed according to 8 standards of National Educational Standards (SNP) that covers minimal criteria of educational components that consists of (1) contents, (2) proces,(3) output competency, (4) human resources, (5) facilities, (6) managements, (7) finacial, and (8) assessment.The 8 standard of quality assurance supported condition and 
requirements for developing quality of education ([6]; [7]; [8]; [9]; [10]).

Revered to that standard, MAN ICG is a senior high school that is characterized by moslem school that is delivered by Minsitery of Religion Affairs that is able to do quality assurance according to NSP. Innovation has been done according to the 8 standards of educational institution to prepare candidate leadership in the future. MAN ICG has done regional, national, and international prestation (profil MAN ICG 2015).

The objectives of the research are to describe (1) how are the commitment of head master and teachers in strengthening quality assurance in accreditation based, and (2) how are students' commitment in maintaining quality of education in MAN ICG.

\section{LITERATURE REVIEW}

One of the main aspects that will be assured school development for deveqloping its status in educational competitive era and global era is quality assurance. The quality assurancc is way way to manage a comprehensive and integrative organization that is focused on Cuustomer needs consistently and contonous improvement in each program and activities in educational iinstitution ([11]; [12]; [13]; [8]; [14]; [10]).

The developing a quality of education is a study how sachool education is managed effectively, and balance to reach a quality of education hopefully. According to ([11]; [14]; Zamroni2017; [9]; [8]) are stated that school quality development is a continoussistematic process to develop quality of teaching and learning process, supported factors, and effective and efficient achievement objectives. In addition, it is also supported by teachers hold high expectation for all students, and school culture [15].

A quality school or not quality school is according to a headmaster leadership because he or she is a top leader of a school, and he or she makes decision for every things, about teacher recruitments, teacher rotation, and teacher promotion. Headmaster role is a manager, very complex, not only to develop curriculum, but it is also developed human resources, facilities, and manage financial of schools. Therefore, he has to have three intelligences: professional intelligence, personal intelligence, and managerial intelligence. Beside, he has to develop quality of teaching and learning process and students' achievement.

The main key for developing quality of education is teachers. A good education has to be supported by capability of teacher, loyalty, integrity, and accountability to do their jobs. The four main tasks, teacher's have to be professional ([16]; [17]; [5]).

The professional teacher will be indicated by teachers' commitment to implement a quality of teaching and learning. A teacher has to develop their current science and technology and gives innovative ideas in curriculum implementation in the class for further developing of quality of teaching and learning. Students have important roles as main actors. The developing of students' role on education will have positive impacts to quality of teaching and learning. There are two factors for developing students' role in teaching and learning, they are internal factor and external factor. Students have important roles for achieving, vision, mission, and school objectives and goals. Schools without students' participation, each school program and activity cannot be achieved.

In order to maintain and control of development of quality process, we have to use national standard to evaluate the successful in developing quality of education. The decision of Indonesian government no.32 year 2013 about the revised low of the Indonesian government no. 19 year 2005 national education standard aims to develop quality of education in Indonesia that consists of (1) content standards, (2) process standard, (3) output competency standard, (4) standard of education staff, and administrative staff, (5) facility standard, (6) management standard, (7) standard of teaching and learning process, (8) education assessment standard.

Quality assurance relies on outside auditors coming inside a school to evaluate how well it is doing. Therefore, accreditation has become important mechanism within education to offer educational program in specific area (Allais, 2017). School or madrasah accreditation is a comprehensive assessment process toward qualified education program that is formulated in qualified certificate issued by Independent Professional Certification (BAN- S/M, 2010). The result of school accreditation are stated at school at three level of schoolAccreditations and symbolized by A (very good), B (good), and C (enough). The accreditation is done to assist educators and institutions in search of quality assurance to continuously improve their program (I Wang, 2006).

\section{METHODOLOGY OR RESEARCH METHODS}

The research used a qualitative descriptive with case study. The type of data were qualitative according to the research sub focus. The research sub focuses were (1) commitment of headmaster and 
teachers instrengthening quality of students in Accreditation based, and (2) students' commitment in maintaining quality of MAN ICG. Source of data were headmasters of Madrasah, vice headmasters, teachers, and students. Data were collected by using observation, interview, and documentation. Data were analyzed qualitatively at data collection, data reduction, data display, and drawing conclusion/verification. Data validation were done by extensional observation, intensive observation, source and data triangulation, and member check.

\section{RESULT AND DISCUSSION}

\subsection{Commitment of Leader and Teachers in Strengthening the Quality Based on Accreditation at MAN InsanCendekiaGorontalo}

Research findings indicate that strengthening quality of education in MAN ICG were done by fulfilling the all requirements for all standards according to National Standards of Education (BAN-S/ that consist of (1) contents, (2) process, (3) graduation or outputs competency, (4) human resources, (5) facilities, (6) management, (7) financial, and (8) assessments.

The standard of the content is in accordance with the regulation of the Minister of National Education RI no 22 of 2006 which contains the basic framework of curriculum, curriculum structure, learning load and academic calendar. MAN ICG strives to fulfill the steps of the standard of the content performed as much as possible. The basic framework of the curriculum in MAN ICG is based on the subject groups associated with the curriculum development system following the national subjects. The curriculum which is added to several subjects namely the international curriculum of Cambridge University. The hope is that students can compete in the Olympic event of science both in national and international level. Systemic curriculum development is also added to several subjects, that is matriculation program. The goal is to equate the basic concepts of science, especially in groups of subjects MIPA plus economics and geography and equality of knowledge of Islam and Islamic religious skills. This matriculation program is devoted to new students who have been accepted and implemented for a month before entering into regular learning. This is in line with Law No. 20 of 2003 chapter X on curriculum, article 36 point 1 stating that curriculum development is done by referring to SNP to realize the goals of national education.A curriculum is expected to provide a foundation, content and guide the development of students' abilities optimally in accordance with the guidance and challenges of community development. In addition, curriculum development must be in accordance with the principle of implementation.

The structure of the curriculum of MAN ICG in determining the list of subjects, local content and self-development in accordance with national standards. For a list of additional subjects, there are on the modified curriculum content of the cambridge of international and matriculation curriculum added into some subjects. For local content nationally called Local Content, consisting of tahfidzulqur'an which is characteristic of MAN ICG and teenager's mkkscientific paperis the national characteristic and there are some self development activities among them; UKPD of music art, UKPD of sports, lifeskill, calligraphy, journalism and computer network. Implementation of learning loads based on weekly face-to-face activities, structured assignments and unstructured self-assignment are the stages to be met by MAN ICG. In its implementation, the three stages have become one unity coupled with the application of SKS. Weekly face-to-face activities have an additional few hours for major subjects with a total of 47 hours per week for all levels, for the assignment of structured tasks that the teacher does in accordance with the subjects taught. Provision of structured tasks is a program that has been published in the subject so that it is easier for students in doing the tasks as well as possible according to the time specified by the teacher. Unstructured selfemployment is an activity that is not programmed into the subject. Time for unstructured selfemployment usually appears when the teacher explains the material and the students contribute ideas. These ideas can then be assigned unstructured tasks by the teacher and the time is determined by the students.

In order for the established curriculum to run well, then the implementation needs to be arranged in the educational calendar. The education calendar is a guideline for the implementation of all activities in the school. The arrangement of the educational calendar is partially tailored to the calendar of the local government, and is only enforced at the beginning of the school entrance and also on the execution of the national exam, the rest is MAN ICG compiling its own calendar.

The arrangement of the educational calendar involves the academic and is assisted entirely by the curriculum development team and the management quality network of madrasah. This is in line with [18], primary and secondary education units can prepare educational calendar according to regional needs, school characteristics, students' and community's needs with regard to education calendar as contained in the content standard. 
Process standard is the criteria on the implementation of learning in educational units to achieve graduate competency standards. One that is related to the process standard is supervision of the learning process. This is in line with ([19]; [20]) which state that supervision on the implementation of all learning activities must dilakukakan continuously to correct and detect irregularities so that the quality of learning can be controlled. The quality control in the learning process at MAN ICG is divided into three activities: monitoring, supervision and reporting.

Monitoring activities are closer to the preparation activities. Preparation of the monitoring process is done at a special time at the end of the school year. In these activities, teachers are facilitated in the preparation of syllabus and learning tools as a whole and the preparation of the instruments used during the implementation of the learning process. There are two activities conducted by the head of the madrasah in conducting supervision activities namely, general academic supervision and clinical supervision. Supervision in general is basically done to see how the existing learning process can be done well and done to avoid the effective hours become empty. While clinical supervision is done if there are complaints from students and teachers related to learning. Further reporting activities are given responsibility to the academic to be able to coordinate and assisted by related staff and based on the direction of the management quality of curriculum development team.

MAN ICG establishes minimum standards and competencies that must be owned by educators and education personnel in accordance with the SNP. To improve the quality of madrasah, MAN ICG sets minimum standards for principals and teachers to teach. The minimum standard of the head is Master Degree educated and has had five years of teaching experience. In addition to academic standards, principals are also required to have the required competencies (Permendiknas No 13/2007), among others (1) personality, (2) managerial, (3) entrepreneurship, (4) supervision, and (5) social. In order for the principal to manage the school professionally, it is also required to have expertise according to the principal's standard (1) leadership skills, (2) educational skills, (3) management skills, (4) administrative skills, (5) supervision skills, and (6) ) motivational skills.

The minimum standard of teachers of MAN ICG is Bachelor Degree educated and preferably Master Degree graduated. The standard of teacher acceptance consists of three tests namely; national exam test questions, Olympic testing test, and SBMPTN test. This indicates that the standard input of educators at MAN ICG always pay attention to the quality of human resources, this is reinforced ([21]; [22]) the quality of human resources is referring to the level of knowledge, ability, skill, and willingness to be Demonstrated by human resources to realize the quality of its performance in producing quality learning process.

[23] states that quality is (1) the degree excellence and distinguishing nature of attribute of education, (2) the ongoing process of building and sustaining relationship by assessing, anticipating, and fulfilling stated and implied needs. To achieve the quality of learning in MAN ICG, there are four competencies that must be possessed by teachers to be accredited, namely (1) pedagodic competence, (2) personality competence, (3) professional competence, and (4) social competence. This is in line with Masaong (2012) signaling that teachers can work to perform their functions and achieve school goals, teachers must have the following competencies: (1) teachers must be able to perform their roles successfully, (2) teachers must be able to work In an effort to achieve educational goals in schools, and (3) teachers should be able to carry out their role in the process of teaching and learning in the classroom.

Teacher quality is an indicator to maintain the quality of learning in MAN InsanCendekiaGorontalo. The quality of learning is at the core of a quality school. Empirically, the teacher of MAN ICG has commitment, high dedication, and professionalism in learning so that student achievement can be maximized. This is in line with ([24]; [25]) guiding all competencies and positive behaviors in the work environment maximally because the sense of belonging and loving work will improve school performance.

Improving the quality of human resources to be a priority of MAN ICG to be consistent in quality assurance, for that MAN ICG provide program of competency development of educators and education personnel by facilitating them in the form of training activities. Furthermore, MAN ICG also tries to develop it by implementing ISO 9001: 2008 quality management system in every activity pattern. This is in line with (Ivancevich, 2007; [26]), that education and training are forms of activities that teachers / employees can provide to improve their knowledge, skills, experience and attitude changes to improve performance, update skills in line with progress Technology, improve work competence, help solve operational problems, prepare employees / employees for the vision of the organization and the fulfillment of personal needs.

Facilities is one of SNP that is not less important with other standards that must be met by each school in improving the quality of school. 
Completeness of facilities is a very important factor. According to [8] states that quality education process should be supported by personnel, such as administrators, teachers, counselors and administration of quality and professional. It is also supported by the facilities and infrastructure of education, facilities, media, and adequate learning resources, both quality and quantity and sufficient cost, proper management, and supportive environment [27]. This is in line with [28] a good means of infrastructure if able to provide breadth to students to learn and effective use by students.

Facilities of MAN ICG are divided into three, they are; (1) infrastructure building complex (GA), consisting of receptionist room, living room, meeting room, dining room, post office, the principal office, headroom of administration, Personnel room, financial room, student room and school committee, photocopy room, infrastructure room, public relations room, ATK warehouse space and bathroom / WC room. All the rooms are equipped with adequate facilities and facilities. (2) facilities of educational building complex, consist of cyber library, library, teacher room, guidance and counseling room, laboratory room, computer room, multimedia room, classroom, academic room, bathroom and toilet All of which have been prepared in accordance with national and international standards, (3) supporting facilities / infrastructure, consisting of, multipurpose building, Sport Center building (in which there is a fitness room, table tennis room), a place of worship, a polyclinic with complete health facilities, Cooperative building, and swimming pool.

MAN ICG in fulfiling education management standards in accordance with national standards of education regulated in the regulation of education minister no. 19 of 2017 with aspects: create and develop program planning, implement school work plan, conduct monitoring and evaluation. MAN ICG tries to adjust to the components that have been set. There are three small teams formed to complete the vision, mission, goals and targets of Madrasahs. The first is the curriculum development team and the madrasah quality network (PKMM), which is coordinated and helps to provide assistance to the academic field. Secondly, the coordination of teamwork under the Deputy Head of Madrasah in the field of living in a dorm for the consolidation of personality and morals (PKAS) and the third team whose work is under the coordination of the Deputy Head of Madrasah in the field of student achievement team and student work (PPKS). These three teams are helping to formulate the formulation of the vision, mission, goals and targets of the madrasah. In order to realize the contents of the vision, mission, goals and targets of the madrasah, it is necessary to make School Work Plan (RKS). RKS is prepared based on the vision, mission and objectives of the school. According to [29] that the school work plan contains school activities systematically and directed for a given time frame. The MAN ICG work plan was prepared for a year. The RKS was made a year before entering a new teaching, and the work program in terms of division of tasks had been prepared by the head of the madrasah at the beginning of the lesson. The same applies to schedules related to the division of tasks so that when the execution has arrived, all of the related components already know their respective tasks. In implementing the madrasah work plan does not rule out what has been arranged will experience a slight shift but of course this will be immediately revised again by the head of the madrasah.

The implementation of school work plan will run well if there is supervision. This is supported by [20], confirming that supervision or supervision of education is none other than providing services to education stakeholders, especially to teachers, both individually and in groups in an effort to improve the quality of the learning process and outcomes. The monitoring process in MAN ICG consists of internal audit and external audit. Since 2013, MAN ICG is equally committed to implementing quality management in every activity undertaken in Madrasah. For the internal audit process, responsibility is given to several established teams. In conducting the audit, the team has different tasks. Meanwhile, for supervision in budget management from Inspectorate General of Ministry of Religious Affairs and from BPKP Gorontalo province. Externally, for supervision of madrasah quality management, an institution that provides or issues ISO 9001: 2008 quality management certification is the united registrar of certification system (URS).

To support all the management operations, financing standards at MAN ICG are adjusted to SNP financing standards that are divided into three aspects, namely investment costs covering the cost of providing facilities and infrastructure, human resources development, and fixed working capital. Personal costs include the cost of education that must be spent by students to be able to follow the learning process regularly and continuously. And operational costs include the salaries of educators and education personnel as well as any allowances attached to salaries, materials or educational consumable equipment and others.

The investment cost available in MAN ICG is managed effectively and efficiently in order to achieve the stated objectives. The management procedures follow the management of state finance 
and to finance facilities and infrastructure, human resources development and fixed working capital, funds from DIPA taken from APBN funds. The personal costs that exist in MAN ICG include the costs that must be spent by parents of students for food allowance. In addition, other dependents are financed by the school. As for the operational costs related to the salary of teachers and educational staff, as well as all allowances attached to salaries, materials or equipment of education and other disposable funds from DIPA taken from APBN funds.

The assessment standard is the latest standard in strengthening the quality of MAN ICG. There are two assessments conducted by MAN ICG, namely the normative and technical assessment. Assessment includes final semester and final semester examinations. Assessment is normatively directed to measure the achievement of student competence that is evidenced by achievement. Technically, the assessment procedure can not be separated from the aspect of standard content and the competence of graduates. Assessment begins with the preparation or analysis of minimum completeness criteria by each subject team and in the execution, each teacher compiles a script or instrument that will be validated first by each team. For assessments made by the educational unit in the final assessment activities of the madrasah or the final examination of the school and the national examinations are carried out on a computer-based basis known as Computer Based Exam. As for the reporting mechanism in the ICG MAN done digitalization and online through SIMANIC application (The Information System of MAN ICG).This is done because students of MAN ICG come from all provinces and all parents can access the acquisition value of their children.

\subsection{Students Commitment in Maintaining Quality of MAN InsanCendekiaGorontalo}

In order to have a quality output or graduation according to MAN ICG target to fulfill output competency standard based aptitude development, knowledge, and skills, MAN ICG has facilitated to give good quality each sectors especially in quality of students. The aptitude development havebeen implemented to students earlier through system implementation for building students' characters to bring them to be better. Students' aptitude of MAN ICG in social interaction are respect aptitude each other, care, andresponsible each other.
Science and knowledge development that wer given by teachers to students were not monotone. Students were given knowledge not only in class but also were given ata outside the the class in order to have factual and conceptual knowledge, for instance they learned at the library, and dormitory or appartement. Teachers gave students soft skills and hard skills in order to express themselves for developing their products, and they developed their competency with creativity with some entrepreneurship events.

There are a lot of activities that students have done to maintain quality. They are (1) keep honesty, (2) to fulfill the rule of school, (3) care and appreciation each other (4) keep the trust given, (5) to take care human relation (6) to be responsible to do tasks, (7) take care reputation of schools, (8) to take a part at local,national, and internationalolimpicscinecies(9) active participation students olimpic research and other compettion, and (10) to do the activities for instance, THE KING, excellent, SCIC (scout competition of InsanCendekia), friendship competition.

Students and staff of MAN ICG supported each other and had commitment to maintain quality of the school in order to have quality assurance to stake holders. One the most students' prestationsin their commttments is to have the best integrative facts at national level in 2016.

The best integrative facts have been given by MAN ICG when it found until today by applying the role of prohibition with consistency and well commitments, especially the students' commitment to follow and apply the rules of MAN ICG, and they are also consistency to have punishment if they have mistakes. The application of the system punishment formulated students' honesty characters that became integrative facts done by students.

MAN ICG strategy in maintaining the integrity is students and staff commitment. The implementation of system that has been done, has been assessed by Ministery of Education with the high integrity assessment in implementation national examination year 2016 as evidents of implementation system has been done well. The active participation of students in maintaining national integrity is begun at honesty with themselves,and responsible to do the best.The Rewards that are givenby MAN ICG at the high integrity of school in implementing national examination have been done very well as the evidents of quality assurance done by MAN ICG to enrich the quality assurance of academic program. This is supported by [6] said that quality is whole figuration and characteristics of graduation as output that show their competences and their satisfaction that have been set up., for instance final 
examination, the acceptance of outputs (graduations) at a favorite university, and they have strategic positions in government institutions.

\section{CONCLUSION SUGGESTION}

AND

There are two conclusions to be taken. First, Head master and teachers' commitments in strengthening based accreditation quality have been done based on NasionalStandard of Quality Assurance of Indonesia that has been regulated by the government of Indonesia that are (a) additionalCambridge internationalcurriculum at MAFIKIBI plus economics and geography, (b) implementation matriculation program for MAFIKIBI plus economics, geography, and Islamic studies for new students before coming into the classroom, (c) giving local contents for memorizing Al Qur'an and KIR, (d) IT based assessment of cognitive, affective, and spychomotoric aspects by applying SIMANIC. (e) enough facilities for teaching and learning process, and (f) maintain social quality, students, and quality of teachers as models.

Second, Student's commitment in maintaining quality of MAN ICG have done by (a) maintain honesty value, (b) fulfillment of Madrasah requirements, (c) take caring, and respects to others, (d) take care duty that has been given, (e) maintain human relation, (f) responsible for carrying out the tasks, (g) maintain positive image of MAN ICG, (g) take parts very good prestation in local, national, and international prestation, (h) have activity of THE KING, excellent, SCIC (scout competition of Insan Cendekia), friends excebition, etc.

Finally, it is suggested to headmasters do continuos and sustainable supervision to school staff for supporting quality of school programs. Teachers are suggested to develop strategies for advicing students' potency in academic and non academic.

\section{ACKNOWLEDGEMENTS}

I would like to extend my special gratefulness to State University of Gorontalo who has given me opportunity to do research, and give financial support for delivering a research. I also say thanks very much to Head Master of MAN Cendekia and staffs who have already facilitated to do a research at that school. This research has a significant contribution to theory of educational management, and quality assurance in education.

\section{REFERENCES}

[1] Scheerens, J. \&Bosker, R. J.1992.The Fundations of Educational Effectivines.London : Cassel.

[2] Sallis, E. 2007.Total Quality Management In Education;ManajemenMutuPendidikan. Jogyakarta: IRCiSoD.

[3] Satori,D. 2008. Sistem Penjaminan dan peningkatan Mutu Pendidikan. Makalah Konvensi

[4] Arifin, I. 2007. Strategi Kepala Sekolah Capai Prestasi Juara UKS Nasional. Kasus TK Anak Saleh Malang. Malang: Aditya Media.

[5] Mas, SittiRoskina.2013. Pengelolaan Penjaminan Mutu Pendidikan Madrasah Aliyah Negeri Jurnal Manajemen Pendidikan.Vol. 24.Nomor 2.

[6] Komariah, A.\& Triatna, C. 2005.Visionary Leadership. Menuju Sekolah efektif.Jakarta: Bumi Aksara.

[7] Creech,B. 1996. Lima Pilar (Manajemen Mutu Terpadu) TQM, Cara Membuat TQM Bekerja Bagi Anda. (Edisi Bahasa Indonesia). Jakarta:Binarupa Aksara.

[8] Bafadal, I. 2003. Seri Manajemen Peningkatan Mutu Pendidikan Berbasis Sekolah. Peningkatan Profesionalisme Guru Sekolah Dasar.Dalam Kerangka Manajemen Peningkatan Mutu Berbasis Sekolah. Jakarta: Bumi Aksara.

[9] Prabowo, S.L. 2008. Penjaminan Mutu Kurikulum di Madrasah. Jurnal El-Hikmah. Volume V.Nomor 2.

[10] Beare, H. \& Caldwell, B.J. \& Millikan, R.H.1989. Creating An Excellent School. Routledge. London and New York.

[11] Sallis, Edward. 2012. Manajemen Mutu Terpadu Pendidikan. Jogyakarta: IRCiSoD.

[12] Tenner, A.R \&Toro,D. 1992. Total Quality Management: $\quad$ Three SteppsToContinous Improvement. Reading, MA: Addison Wesley Publishing Company.

[13] Koswara, Deni. 2012. Manajemen Pendidikan. Bandung: PT RemajaRosdakarya.

[14] Ascaro, J.S. 2006. Pendidikan Berbasis Mutu. Prinsip-Prinsip Perumusan dan Tata Langkah Penerapan.Yogyakarta: Pustaka Pelajar.

[15] Lyons, Robert and Barnet, David.2011. Scool Audit and School Improvement Exploring the Variance Point Concept in Kentuky's Elementary, Middle, and High Schools. International Journals of Education Policy and Leadership. January 17, 2011 vol 6 No 1.

[16] Rosyada, Dede. 2015. Creative Thinking, Kolom Rector UIN SyarifHidayatullah, Jakarta. Prenada Media.

[17] Mulyasa, E. 2004.Menjadi Guru Profesional. Bandung: PT RemajaRosdaKarya.

[18] Peraturan Menteri Diknas No.22 Tahun 2006 Tentang Standar Isi.Jakarta: Depdiknas.

[19] Siagian, Sondang P. 1990. FilsafatAdministrasi. Jakarta: GunungAgung. 
[20] Nawawi, Hadari. 2015. Manajemen strategic Organisasi Non Profit BidangPenelitian.Yogyakarta: Gajah Mada University Press.

[21] Ruki, Achmad. 2003. Sistem Manajemen Kinerja. Bandung: RefikaAditama.

[22] Matutina. 2001.Manajemen Sumber Daya Manusia Cetakan Kedua. Jakarta: GramediaWidia.

[23] Quality Council of India. 2008. National Education Board for Education and Training. Second Edition.

[24] Wallace, Jean.E. \& Kay, F.M. 2008. The Profesionalism of Practicing law: A Comparison Across Work Contexts. Journal of Organizational Behavior, (online), 29, 10211047,(www.interscience.wiley.com).

[25] Luthans, F., Norman, S.M., Avolio, B.J, \&Avey, J.B. 2008. The Mediating Role of Psychological In The Supportive Organizational Climate- Employee Performance Relationship.Journal of Organizational Behavior, (online), 29, 219-238, (www.interscience.wiley.com).

[26] Rivai, V \&Sagala, J. 2010. Manajemen Sumber Daya Manusia Untuk Perusahaan Dari Teori ke Praktek. Jakarta: Rajawali Press.

[27] Bafadal, Ibrahim. 2008. Manajamen Perlengkapan Sekolah. PT. BumiAksara: Jakarta

[28] Frymier, J., Combleth, C., \& Donmeyer, R.,Gansneder, B.M.,Jefer,J.T.,Klein, M.F.,Schwab,M., \& Alexander, W.M. 1984. One Hundred Good Schools. West Lafayette, Indiana:Kappa Delta Pi.

[29] Sahertian, Piet A. $1994 . \quad$ DimensiDimensiAdministrasi di Sekolah.Surabaya: Usaha Nasional. 